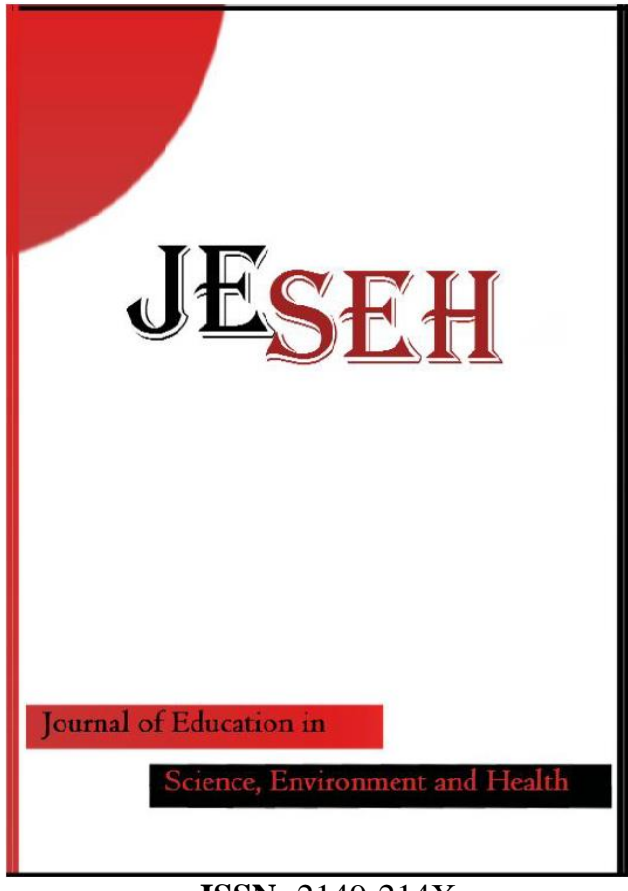

ISSN: $2149-214 \mathrm{X}$

\section{Journal of Education in Science,} Environment and Health

www.jeseh.net

Examining the Relationship between Middle School Students' Critical Reading Skills, Science Literacy Skills and Attitudes: A Structural Equation Modeling

Ersin Karademir ${ }^{1}$, Ufuk Ulucinar ${ }^{2}$

${ }^{1}$ Eskişehir Osmangazi University

${ }^{2}$ Usak University

To cite this article:

Karademir, E. \& Ulucinar, U. (2017). Examining the relationship between middle school students' critical reading skills, science literacy skills and attitudes: A structural equation modeling. Journal of Education in Science, Environment and Health (JESEH), 3(1), 29-39.

This article may be used for research, teaching, and private study purposes.

Any substantial or systematic reproduction, redistribution, reselling, loan, sub-licensing, systematic supply, or distribution in any form to anyone is expressly forbidden.

Authors alone are responsible for the contents of their articles. The journal owns the copyright of the articles.

The publisher shall not be liable for any loss, actions, claims, proceedings, demand, or costs or damages whatsoever or howsoever caused arising directly or indirectly in connection with or arising out of the use of the research material. 


\title{
Examining the Relationship between Middle School Students' Critical Reading Skills, Science Literacy Skills and Attitudes: A Structural Equation Modeling
}

\author{
Ersin Karademir, Ufuk Ulucinar
}

\begin{tabular}{|c|c|}
\hline Article Info & \multirow{11}{*}{$\begin{array}{l}\text { Abstract } \\
\text { The purpose of this study is to verify the causal relationship between middle } \\
\text { school students' critical reading skills, science literacy skills and attitudes } \\
\text { towards science literacy with research data according to the default model. } \\
\text { Through the structural equation modeling, path analysis has been applied in the } \\
\text { study which was designed in correlational model. The sample of the study } \\
\text { consists of } 1170 \text { students enrolled in } 18 \text { schools determined based on socio- } \\
\text { economic status. However, the results showed that validity criteria was satisfied } \\
\text { with the } 1130 \text { participants. As data collection tool, the scale of critical reading } \\
\text { skills, science literacy skills test, and the attitude scale toward science literacy } \\
\text { were used. Descriptive statistics, Pearson product moment correlation analysis } \\
\text { technique and path analysis were employed for the data analysis. The findings of } \\
\text { the research show that there are significant and positive relations between critical } \\
\text { reading skills, science literacy skills and attitudes towards science. In addition, } \\
\text { critical reading skills have a statistically positive predictive effect on science } \\
\text { literacy skill. It has also been founded that science literacy skills predict the } \\
\text { attitudes towards scientific literacy in a meaningful way. Moreover, critical } \\
\text { reading skills directly predict the scientific literacy in a meaningful, positive } \\
\text { direction. It has been revealed that science literacy skill, which exists in the } \\
\text { model, acts as partial mediating variable. As a result, as put forward in theory, } \\
\text { critical thinking, critical reading skill, and science literacy skills and attitudes } \\
\text { have been found to be closely related. }\end{array}$} \\
\hline Article History & \\
\hline Received: & \\
\hline 25 May 2016 & \\
\hline $\begin{array}{l}\text { Accepted: } \\
09 \text { November } 2016\end{array}$ & \\
\hline Keywords & \\
\hline $\begin{array}{l}\text { Middle school students } \\
\text { Critical thinking }\end{array}$ & \\
\hline Critical reading skill & \\
\hline Science literacy skill & \\
\hline Attitudes toward science & \\
\hline literacy & \\
\hline
\end{tabular}

\section{Introduction}

In today's science education, gaining 21 st century skills such as digital age literacy, exploratory thinking, effective communication and high productivity has become an increasingly popular topic in the international debate within the science curriculum attainments (McGregor \& Kearton, 2010). As one of digital age literacies, scientific literacy is an output of targetting the knowledge and approach related to scientific concepts and processes to ensure personal decision making, participation in social and cultural relations and economic productivity. Since intertwined with science and technology, it has been accepted as important in our modern society (Turin man, Omar, \& Osman Daud, 2012). Smith, Loughran, Berry and Dimitrakopoulos (2012) argue that because of the complexity of the concept of science literacy and different learning expectations about desired learning outcomes from students, what it means exactly in terms of in-class applications and students' learnings is a controversial issue. However, it is now seen as an objective of educational program and an essential component of conscious citizenship in many countries around the world. Not only in formal education, but also in science and art centers, museums, written and visual media, scientific journals, politics, medicine, film and drama, improving science literacy are investigated (Jenkins, 2010). Because, in terms of helping students to see how scientists think and reach scientific conclusions, it is both a fundamental component of science education and a fundamental objective of science literacy (Lawson, 2010). Within the goals of the educational program in question, as well as providing students to gain scientific concepts, content and conceptual knowledge; scientific classifications, time, and developing cognitive concepts about causality of both physical and psychological events take part as well (Westby \& Torres-Velásquez, 2000). In terms of literacy skills, science learning takes place by learning how to use the language of science as well as learning the facts and definitions or experimental process of science. As a result, learning a language requires opportunities to use it and writing science in standard forms (Wellington and Osborne, 2001). Thus, Yore, Hand, \& Florence (2004) defined that a literacy skill includes language-based actions like reading, writing, listening, speaking and monitoring. Although each action takes place in the context of all disciplines, it is claimed that language is the basis of learning science and therefore science literacy. 
Act of reading, as well as having an important role in the acquisition of science is one of the main attainments of the many native language programs. Most of the time, reading is seen as an action that students take only to find out the information in the text. In this reading process, students just look for some facts and assume that the resource is true. Since this reading process takes place in a period of time as short as possible, it limits students' use of mental skills (Wheeler, 2007). Most of the teachers at schools today, unfortunately, can not prepare their students as critical thinkers. For this reason, many of the students have stated that they have been unable to develop adequate critical reading skills (Kadir, Subki, Jamal, and Ismail, 2014). In terms of educational view, in order for a student to be a critical reader, he/she should spare time to examine the argument in the text in logical, theoretical, historical, ethical, social, and personal aspects because critical reading involves a thinking process that questions the results and the accuracy of these results in the text the reader deals with.Thus, critical thinking, which is a kind of high-level thinking skill, requires a reader to participate in reading process in an active and constructivist way. In order to prepare students for a complex world as more scientifically and technologically, the best education applications are required. Starting from pre-school, children must learn to be able to think critically, to integrate information correctly and to solve problems in new situations (Center for Science, Mathematics, and Engineering Education, 1998). In this research, by putting forward the causal relationship between critical reading skill as high-level thinking action, science literacy out of the $21^{\text {st }}$ century skills and attitudes towards science literacy, it has been aimed to make recommendations about the goals and objectives of the educational program.

\section{Critical Reading}

Accepted as an education ideal, higher order thinking (Siegel, 1988; Lipman, 1995), is a skill that all educators agree on importance of its achievement (Shahrokh, 1998). As in all disciplines, in reading education, too, the development of higher order thinking skills is emphasized (Collins, 1993; Paul \& Elder, 2008; Zabihi \& Pordel, 2011; Barnett \& Bedau, 2011). Reading, comprehension, analysing and integration of a text is the basis of reading. For this reason, reading is a process which lays out a higher order thinking potential. Higher reading comes true effectively when the reader can relate the known with new information in order to answer some questions (Collins, 1993). According to Criscuolo (1965), critical reading is a critical process in which higher order mental process is used for interpreting and evaluating the information read. In this process, while developing his critical reading skill, a student must compare what they read with the previous information. In the context of the relationship between critical thinking and critical reading, critical thinking means critical reading. According to researchers explaining critical reading with critical thinking skills, critical reading is students' technique of analyzing what they read, synthesizing and evaluating (Kadir, Subki, Jamal and Ismail, 2014; Akin, Koray and Tavukcu, 2015), discovering the information and evaluating (Zabihi and Prodel, 2011). Paul and Elder (2008), stated that critical reading is the art and science of evaluating and analyzing a text using a perspective to improve the nature of thinking and behavior of the individual. According to Paul and Elder, critical reading strategies contain: (1) identifying a problem or issue, (2) establishing meaning (3) making interpretation in line with the evidence, (4) providing strong assumptions, (5) making applications and (6) taking a different perspective. If the student does not make an interpretation for the text in the simplest level, it is unlikely for him to understand the text (Burnett and Berg, 1988). So, critical reading should be seen as an educational ideal in schools. According to Lewis (1983), the purpose of teaching critical reading is to grow individuals who can reach some judgments about what they read depending on strong evidences and very strong reasoning process more than subjective data. Together with this purpose, it helps individuals to develop thinking strategies. It was found that while individuals reading critically had more important notes and markings, those who read less critical took less summary notes. At the same time, critical readers tend to take critical notes and make marking through reading course process (Kobayashi, 2007). Effective critical readers have a number of strategies that are used to improve their critical thinking skills (Walker, Kiefer and Reid, 1994-2012). These techniques represent ways to talk about ideas, graphic organizers and story maps for narrative texts (deVoogd, 2007). On the other hand, Yang (2006), has studied to find out the relationship between reading strategies and comprehension monitoring strategies and how these strategies affect their understanding process. In the study, it was found that reading strategy is a mental process that is used while solving problems caused by the lack of language skills in the process of an individual's understanding of the text. Aregu (2013), unlike, has examined the effects of self-learning strategies on critical reading performances, and the study results showed that learning strategies have significant effects on critical reading performance. 


\section{Science Literacy Skill}

Because of the complexity of the concept and different learning expectations about desired learning outcomes from students, what science literacy, one of 21st century skills, means exactly in terms of in-class applications and students' learnings is a controversial issue (Smith, Loughran, Berry and Dimitrakopoulos, 2012). Pella and others (1966) who made first studies on scientific literacy, suggested the qualifications that a science literate individual should have. According to them, science literate individuals should (a) have science and the internal relations of society (b) and the ethics controlling the studies of scientists, (c) have the understanding of the science of nature, (d) know the difference between science and technology, (e) know the basic concepts of science and (f) have the understanding of internal relations of individuals and science. Moreover, according to Aron (1983), these individuals have the ability to (a) define that scientific concepts are discovered or created by the actions of human intelligence and imagination; (b) understand the difference between observation and inference; (c) form hypothesis in a planned way and realize testing methods and (d) define their own learning methods, be aware of the reasons of what they believe and prove the evidences they reach on the subject they examine. On the other hand, it is seen that whole of scientific literacy has been defined in four componenets at PISA 2006. Scientific context (living conditions including science and technology, etc.); scientific skills (identifying scientific issues, explaining a phenomenon with scientific explanations and using scientific evidence); learning areas for scientific knowledge (understanding of nature related to the science as well as the understanding of students about the scientific concept) and attitudes towards science (interest in science, scientific inquiry support and to have responsibility for resources and the environment) (OECD, 2006).

In the context of educational activities, it has been revealed that creative and collaborative learning environment (Oluwatelure, 2010), inquiry-based learning community (Nwagbo, 2006; Lewis, 2010), metacognition-based training (Michalsky, Mevarech and Haibi, 2009), authentic scientific inquiry (Hume, 2009) socio-critical and problem solving based chemistry teaching (Marx and Eilks, 2009), teaching based on scientific process (Genç, 2015), the use of scientific texts (Parkinson's and Adendorff, 2004), integrated teaching strategies approach (Webb, 2009) and argumentation method (Washburn and Cavagnetto, 2013)improve science literacy skills. Furthermore, Lin Hong and Huang (2012), studied the relationship between students' affective characteristics such as interest, enthusiasm and participation in science education and scientific literacy. It has been found that interest, enthusiasm and participation that students have in learning science increase their science literacy skill.

\section{Relationship between Critical Reading Skills, Science Literacy Skills and Attitudes towards Science Literacy}

Science literacy and critical reading are intertwined with each other. Because, an individual must be able to think along with the evidence to be a science-literate. For this, a combination of the high-level language and thinking skills are needed (Hackling and Sherriff, 2015). Wellington \& Osborne (2001), pointed out that reading is a scientific activity. They stated that the ability to read in a careful, critical and a healthy doubtful manner is the basic feature of being a scientist and that the skill to read critically, carefully and with a healthy sceptisizm is the main component of science literacy. Learning of science texts thoroughly depends on such skills as making inferences, drawing conclusions, showing a time sequence and chronology, forming hypothesis, realizing the result. Therefore, the above-mentioned critical reading skills make it possible for students to analyze, to interprete and to evaluate in a critical way the concepts, nature and processes of science. For this reason, as stated in the H1 hypothesis, it is assumed that the critical reading skills predict science literacy skills. In $\mathrm{H} 2$ hypothesis, it is assumed that science literacy skills predict attitudes towards science literacy. The individual's tendency to questioning causal relationship of scientific propositions in scientific texts, trying to understand how it happens in this process, having curiosity and understanding the knowledge about scientific process, reflect the attitude towards science.

An individual who is successful in terms of science literacy skills is thought to have increasing attitudes toward science. On the other hand, critical reading individuals, as previously stated, use such higher order skills as to analyze, to interpret and to evaluate information about the text they read. An individual who has these skills is likely to have a tendency to wonder the knowledge, concept, process or progresses related to science; to try to understand and question them. Accordingly, in H3 hypothesis, critical reading skill is assumed to have an impact on predicting the attitudes towards science literacy. At the same time, within this relationship pattern, science literacy skill is assumed to have the effect of a mediating variable between attitudes toward science literacy and critical reading skills. 
$\mathrm{H}_{1}$ : Critical reading skills of middle school students predict science literacy skills in a meaningful way.

$\mathrm{H}_{2}$ : Science literacy skills of middle school students predict attitudes toward science literacy in a meaningful way.

$\mathrm{H}_{3}$ : Critical reading skills of middle school students predict attitudes toward science literacy in a meaningful way.

$\mathrm{H}_{4}$. Science literacy skills variable has a mediation effect between attitudes towards reading skills and science literacy.

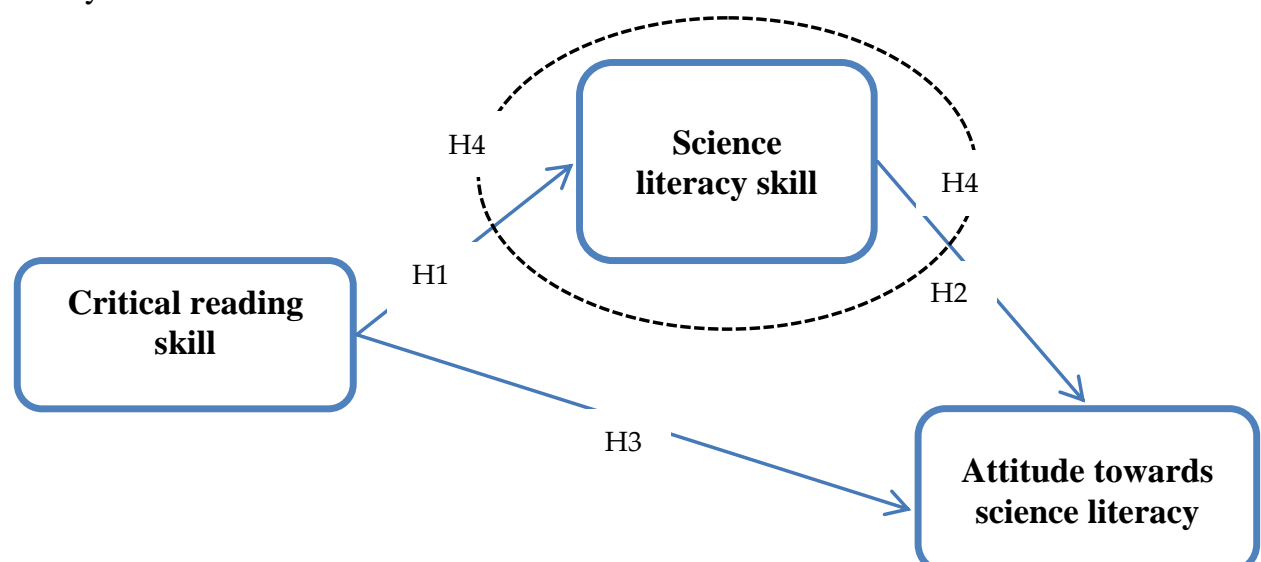

Figure 1. Critical reading skills, the default model of the causal relationship between science literacy and science literacy attitudes towards

\section{Method}

\section{Research Model}

This research, in which the causal relationship between middle school students' critical reading skills, science literacy skills and attitudes towards science literacy is studied, was designed as correlational model. Studies designed by the correlational model are done to reveal the relationship between two or more variables and to obtain results about cause-effect (Christensen, Johnson and Turner, 2015). In the study, path analysis, which is a structural equation model compatible with the research modelling, has been employed. In line with this model, it was aimed to verify the causal relationship between students' critical reading skills, science literacy skills and attitudes towards scientific literacy, according to data collected through the default model. Out of the variables in the default model, critical reading skills have been dealt with as independent variable; science literacy skills as intermediary (mediator) variable and attitudes towards science literacy as dependent variables.

In the default model, one of the two modellings in SEM, structural model was adopted since verifying the structural relations of variables with each other was intended. Before proceeding to testing the model, two conditions are in question in the fulfillment of the suppositions of SEM (Kline, 2012: 112). These are controlling; (1) the existence of a causal relationship and (2) the structure of data distribution. Kline draws attention to five conditions that must be met in a structural model regarding the existence of a causal relationship between two variables (a) the default cause variable should take place before the effect variables. A temporal priority is in question. (b) there should be a covariance or correlation between the cause and effect variable. (c ) in the cause and effect relationships, it must not be affected by other variables that can also affect the effect variable (d) the distribution form of data must be checked. (E) the direction of the causal relationship must be determined accurately (contrary to $\mathrm{Y}$ affecting $\mathrm{X}, \mathrm{X}$ affecting $\mathrm{Y}$ actually or the interaction acting of $\mathrm{X}$ and $\mathrm{Y}$ each other).

\section{The Population-Sample}

The population of study constitutes sixth, seventh and eighth grade students studying in secondary schools in Eskişehir. In the sample, 18 secondary schools took part which have been stratified as upper-middle-low socioeconomic status. In the selection of the students in these schools, the convenient sampling method was applied, 1170 middle school students participated in the research. Following the processes such as extracting extreme values and missing data in scales applied to students, 1130 students' data were included in analysis and 
constituted the study sample. The following table shows the frequency and percentage distributions of demographic information of sample group.

Table 1. Demographics of the sample group

\begin{tabular}{llcc}
\hline \multirow{2}{*}{ Gender } & & $\mathrm{N}$ & $\%$ \\
& Female & 547 & 48.4 \\
\multirow{3}{*}{ Grade } & Male & 583 & 51.6 \\
& Sixth & 379 & 33.5 \\
Total & Seventh & 396 & 35.0 \\
\hline
\end{tabular}

A total of 1130 students participated in the study; 547 of them are (48.4\%) female, and $583(51.6 \%)$ are male. 379 of these students are (33.5) at 6th grade; 396(35.0\%) are at 7th grade and 355(35.0\%) are at 8th grade

\section{Data Collection Tools}

Critical reading skills scale:

In this study, in order to identify students' critical reading skills attainment levels, "critical reading skills scale" , which was developed by Unal (2016), was used. The scale consists of 22 items within critical reading context. The scale is in five-point Likert-type; rated as "Always, usually, sometimes, rarely, never". Cronbach alpha reliability value of the scale was .872 . Reading comprehension- based text samples test: In order to determine the students' science literacy skills and attitudes, reading comprehension-based text samples test (science literacy test) has been used. The test composed of two parts: a) Science literacy skills test: It is prepared to determine the student's science literacy skills; consisting four texts related to science (working under temperature, genetics, solar and electric) and multiple-choice questions that can be answered by making inferences from these texts. Working under temperature and genetics related texts are taken from sample PISA science questions released by Ministry of Education (2013). Science texts about sun and electric have been prepared based on the opinions of three faculty members expert in the field of science education, two science teachers and a Turkish language expert, within the context of sample PISA questions. In this test, students were given texts as presented below. Students were asked to read the text and answer true-false and multiple-choice questions formed according to this text. A sample science literacy skills test question is presented below.

\section{Question 13.1: Working under Temperature}

Murat is working in the repair of an old house. He has left a bottle of water, a bit of metal nail and a piece of lumber in the trunk of his car, After staying under sun for three hours, the temperature inside the car reaches approximately 40 degrees. What happens to objects in the car? For each circle "Yes" or "No"

\section{Is this; happen to the objects?}

They all reach at the same temperature. Yes/ No

After a while, the water begins to boil. Yes/ No

After a while, metal nails start flushing. Yes /No

The temperature of the metal nail is higher than the temperature of the water. Yes/ No

\section{Question 13.2: Working under Temperature S420Q03}

Murat has drunk a cup of coffee at a temperature $90^{\circ} \mathrm{C}$, a mineral water at a temperatura $5{ }^{\circ} \mathrm{C}$ during the day. The cups are in the same shape and size and each drink has the same volume. Murat leaves the cups in a room where the temperature is 20 degrees.

What can be the temperature of coffee and mineral water 10 minutes later?
A) $70^{\circ} \mathrm{C}$ and $10^{\circ} \mathrm{C}$
B) $90^{\circ} \mathrm{C}$ and $5^{\circ} \mathrm{C}$ 
C) to $70^{\circ} \mathrm{C}$ and $25^{\circ} \mathrm{C}$

D) $20^{\circ} \mathrm{C}$ and $20^{\circ} \mathrm{C}$

b) Science literacy attitude scale: There are items related to attitude in each of sample PISA science questions in science literacy skill test released by Ministry of National Education (2013). The scale, in which these are included, is called scientific literacy attitude scale. Sample test items of attitude scale used within the context of the text "working under temperature" are as follows: "Understanding how the shape of the container affects the cooling rate of coffee", "learning about different arrangements of atoms in wood, water, and steel", "knowing why different solids conduct heat differently". Students were asked to read the propositions set out above and to express their attitude with a question in the form of" to what extent are you interested? ".The grading format of Likert-type scale is "high level of concern", "moderate concern," "concern at the low level" is "does not concern".

\section{Data Analysis}

In order to understand whether data-set is compatible with the default model, path analyzes were performed using maximum diversity calculation in AMOS 21.0. In this analysis, the relationship between the variables in the default model were tried to be determined. Before starting Path analysis, descriptive statistics were made on the implicit (latent) and observed variables in the model. In addition, in planned model, the variables called "working under temperature", "electric", "genetics" and "sun" under science literacy skill (latent variable) are observed variables. Under attitude towards science literacy, another implicit variable, "working under temperature" and "genetics" represent the observed variable of the model. On the other hand, critical reading skill, too, was included in the model as observed variable. Arithmetic mean and standard deviation values were calculated for each variable. Pearson Product Moment Correlation analysis technique was applied to demonstrate the relationship between critical reading skills, science literacy skills and attitude variables.

Before being subjected to the path analysis, the model went under missing data and extreme values extraction process. In the arrangement of the data contained in continuous variables (critical reading and science literacy attitude scale)the average of the variables in the same series instead of data losses were calculated by 'Series mean' method. In classified variables (science literacy test), participants data where lost data exists were excluded from the analysis. After the data extraction and editing process, the data was made available for structural equation modeling analysis. Because the researcher is to make the data ready for a software specialized in structural equation modeling studies (Malone \& Lubansky, 2012). In assessing the compliance of the model, chi-square fit test $(\chi 2)$, the comparative fit index (CFI), the incremental fit index (IFI) and the root mean square of about errors (RMSEA) values were calculated (Kline, 2011; Schumacker and Lomax, 2010). The chi-square statistical value $(\chi 2=3.394, \mathrm{df}=12, \chi 2 / \mathrm{df}=.283, \mathrm{p}=.992)$ of the model, which is taken into consideration in testing the general harmony between the default model and the data, describes the competency of model (Bentler, 2006). Also, it is known that $\mathrm{CFI}=1.00$; IFI $=1.010 \mathrm{RFI}=.991$; fit values get acceptable as fit index of the model gets closer to 1 ; on the other hand, as [RMSEA $=.044$ ] value gets closer to 0 , the model is known to show acceptable perfect fit (Arbuckle, 2008).

\section{Results and Discussion}

Descriptive statistics and correlation values for the variables in the study are presented in Table 2 . While science literacy skills scores are at low-level associated with science literacy attitude scores $[\mathrm{r}=.148]$ and critical reading skills $[\mathrm{r}=.098]$, scores of attitude towards the scientific literacy are significantly and positively correlated with critical reading skills at moderate-level $[\mathrm{r}=.346]$.

The figure 2 showing the path analysis which was made to verify the compliance of theory-based created model with data and coefficients of variables' relating to each other are presented below. 


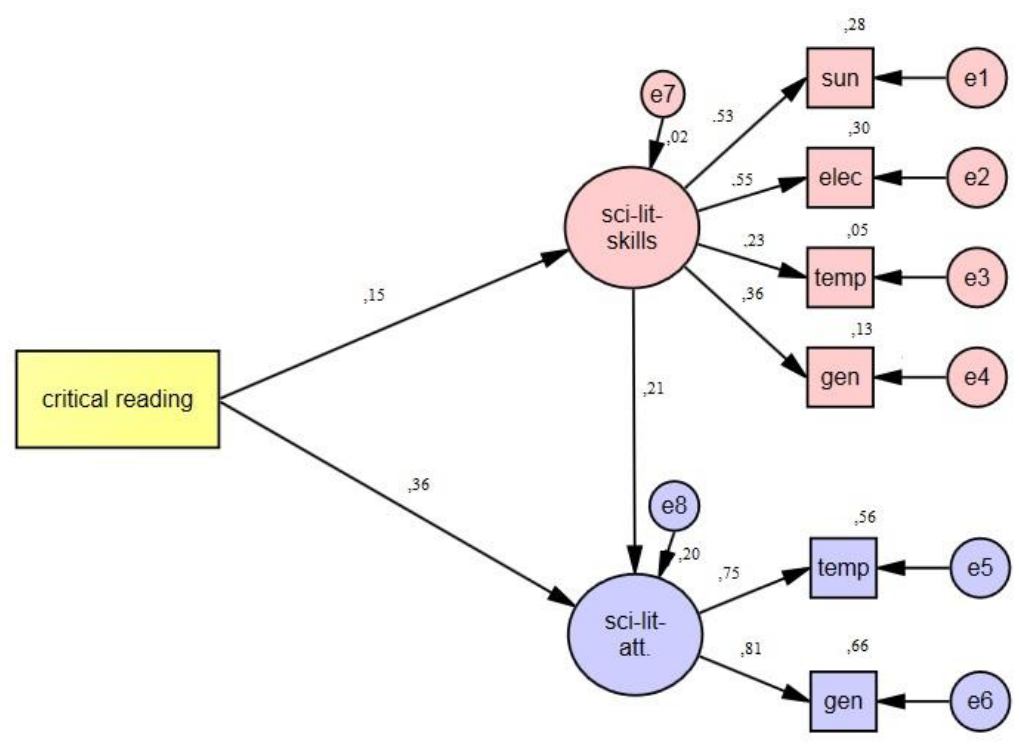

Figure 2. A path model between scientific literacy skills, attitude toward scientific literacy and critical reading skills [Sci-lit-skills: Scientific literacy skills, Sci-lit-att.: Attitude toward scientific literacy, Sun: Sun, Elec.:

Electricity,

Temp.: Working under temperature, Gen.: Genetics]

Table 3. Standardized regression coefficients, standard error and significance values of variables in path model

\begin{tabular}{|c|c|c|c|c|c|}
\hline Independent variable & Dependent variable & $\begin{array}{l}\text { Std. regression } \\
\text { coefficient }\end{array}$ & $\begin{array}{l}\text { Standard } \\
\text { Error }\end{array}$ & (p) & $\begin{array}{l}\text { Explained } \\
\text { Variance }\end{array}$ \\
\hline Critical reading skill & $\begin{array}{l}\text { Attitude toward } \\
\text { science literacy }\end{array}$ & .36 & .023 & .000 & \multirow{2}{*}{$\% 20.2$} \\
\hline Science literacy skill & $\begin{array}{l}\text { Attitude toward } \\
\text { science literacy }\end{array}$ & .21 & .071 & .000 & \\
\hline Critical reading skill & Science literacy skill & .15 & .028 & .000 & $\% 2.3$ \\
\hline
\end{tabular}

As seen in Table 3 , the critical reading skill predict attitudes towards science literacy scores $(\beta=.36)$, and science literacy skills $(\beta=.15)$ in a significant and positive direction $(p<.05)$. According to this result, Hypotheses $\mathrm{H}_{1}$ and $\mathrm{H}_{2}$ are acceptable. On the other hand, science literacy skill $(\beta=.21)$ predicts science literacy attitudes scores in a meaningful way in a positive direction. This finding indicates the acceptance of $\mathrm{H}_{3}$ hypothesis. In addition to this, of the variables in the model, critical reading skill and attitudes towards science literacy scores has been found to represent $20.2 \%$. Critical reading skills explains $2.3 \%$ of the science literacy skills.

Table 2. Science literacy skills test scores, science literacy attitude scores, average, standard deviation values of critical reading skills and correlation coefficients

\begin{tabular}{clllll}
\hline Variables & $\bar{X}$ & s & (1) & (2) & (3) \\
\hline (1) Science literacy skills test & 6.39 & 2.43 & 1 & & \\
(a) Working under temperature & 2.42 & .95 & & & \\
(b) The Sun & 1.31 & .79 & & & \\
(c) Electricity & 1.07 & .78 & & & \\
(d) Genetic & 1.52 & 1.02 & & & \\
(2) Science literacy attitude scale & 3.20 & .64 & .148 & 1 & \\
(a) Working under temperature & 3.18 & .72 & & & \\
(b) Genetic & 3.21 & .72 & & & \\
(3) Critical reading skills scale & 1.07 & .78 & .098 & .346 & 1 \\
*there is a significant at $\mathrm{p}<.01, * * \mathrm{p}<.05$ & & & & & \\
\hline
\end{tabular}


As stated in hypothesis $\mathrm{H}_{4}$, the mediation effect of science literacy skill between critical thinking skill and attitudes towards science literacy was tested. Baron and Kenny (1986) stated that three conditions were to be present for a variable to be mediating variable. These are; (1) independent variable or variables'(critical reading skill) affecting the mediating variable (science literacy skill), (2) mediating variable's (science literacy skill) having a meaningful effect on dependent or dependent variables(attitudes towards science literacy), (3) independent variables' (critical reading skill) showing meaningful effects on dependent variables (attitudes toward science literacy)(see Figure 1.). However, in this model, because the predicting level of critical reading skill and scores of attitude towards science literacy is meaningful, science literacy variable has"partial mediating effect". Moving from this point, in the direction of the default theory, this theory can said to be confirmed. Mediation analysis is performed with the aim of predicting the role of causal mechanisms(variables) that transfer an independent variable's impacts on dependent variable (Hicks and Tingley, 2011).

Table 4. Sobel, Aroian and Goodman tests' results related to significance mediation effect between dependent and independent variables

\begin{tabular}{llllccccc}
\hline $\begin{array}{l}\text { Independent } \\
\text { variable }\end{array}$ & R.C. & S.E. & \multicolumn{2}{l}{ Mediator variableR.C. } & S.E. & Dependent variable \\
\hline $\begin{array}{l}\text { Critical reading } \\
\text { skill }\end{array}$ & .36 & .023 & $\begin{array}{l}\text { Science } \\
\text { skill }\end{array}$ & literacy & .21 & .071 & Attitude toward science literacy \\
\hline Sobel test & $\mathrm{z}$ & $\mathrm{p}$ & Aroian test & $\mathrm{z}$ & $\mathrm{p}$ & Goodman test & $\mathrm{z}$ & $\mathrm{p}$ \\
& 2.58 & .009 & & 2.56 & .010 & & 2.62 & .008 \\
\hline
\end{tabular}

R.C. Regression Coefficient; S.E. Standard error

According to Sobel, Airon and Goodman mediation test results, z values of science literacy skills (mediating) variable's mediating effect between critical reading skill (independent) variable and attitude towards science literacy (dependent) variables are respectively $z$ [Sobel $]=2.58 ; z$ Airon $]=2.56 ; z[$ Goodman $]=$ it is 2.62 . According to $\mathrm{z}$ values calculated in these tests, it was found that the science literacy skill is meaningful as a mediating variable. Proceeding from these findings, science literacy skill variable has a meaningful mediation effect between critical reading skills and attitudes towards science literacy variables in the model. Critical reading skills of middle school students was confirmed by research data-set of structural model constructed with variables indicated in the study examining assumed causal relationship between attitudes towards science literacy and science literacy skills.

Path analysis results conducted in order to test $\mathrm{H} 1, \mathrm{H} 2, \mathrm{H} 3$ and $\mathrm{H} 4$ hypothesis show the significance of causal relationship between the variables in the default model. As tested in H1 hypothesis, critical reading skills predict the science literacy skills of students in a meaningful way. In other words, these finding indicates that students' critical reading skills play an effective role in the development of science literacy skills. When the literature is examined, science literacy and critical reading is observed to be interrelated skills with each other. Because, to be science-literate, an individual must be able to think along with the evidence. To do this, a combination of the higher order language and thinking skills is required (Hackling and Sherriff, 2015). Some studies describe critical reading as critical thinking skills like analyzing and evaluating what they read, exploring and evaluating the information (Kadir, Subki, Jamal and Ismail, 2014; Akin, Koray and Tavukcu, 2015; Zabiha and Prodel, 2011). In addition, Majima (2012) stated that one of the main components of scientific literacy is the ability to critically analyze and evaluate a scientific claim and evidence. These expressions show the presence of critical thinking skills in the development of scientific literacy. Similarly, Viera \& Tenreiro- Viera (2016), reported that science literacy and critical thinking are the basic components of science education. A study, targeting science literacy basically, focusing on critical thinking and including the design, application and evaluation of science learning activities, was carried out. Learning activities which were designed and practiced for 6th grade students, provided a significant impact students' critical thinking skills and science literacy skills. In line with this finding, Blake (2015) explains that science literacy skills require critical thinking. Understanding the science text includes such skills as making inferences, drawing conclusions, showing a time sequence the chronology, forming hypothesis, realizing cause and effect.

Therefore, the above-mentioned critical reading skills of students enable them to analyze, interpret and evaluate the concepts, nature and processes of science in a critical way. Yu (2013), indicates that science literacy skill is intensely based on new words, concepts, information and phenomenons. For him, understanding the contents of scientific texts effectively depends on four factors. These factors are; (1) scientific language, (2) vocabulary, (3) the structure of the text, (4) motivation and (5) the purpose and reading without prior knowledge of. Indeed, Khabir of \& Pakzad, (2012), has determined that teaching of critical reading strategy contributes to students' word retention. Depending on Yu's study, it can be said that students' use of vocabulary more effectively thanks to critical reading strategies improve their science literacy skills. Yu's research result supports the findings of the 
H1 hypothesis tested in this study. It is clear that as well as critical reading skills and critical thinking skills, critical reading strategies have effect on science literacy skills of students. In addition to this inference, Jurečka \& Wander (2012) presented an academic approach in critical evaluation of the scientific literature and other texts. They collected the four-element criteria in two groups. While the first group is originality and competence assessing the nature of the source; the second group is objectivity and validity which assess the nature of the information contained in the source. They develop a concrete evaluation system based on scientific terminology with this approach. The ultimate aim is to improve the students' science literacy skills. Similarly, Geithner \& Pollastro (2016) used peer review in their work in order to improve students' critical reading and writing skills. In this study, the effect of students' peer review related to 'Human Physiology' on science literacy skills has been examined. According to them, peer review has been stated as quite common among 21 st Century learning activities which increase scientific literacy stated These studies clearly indicates that findings related to critical reading in science education are largely related with science literacy skills. As supporting this relationship, Cavagnetto (2010) stated that science literacy skill contributes to increasing of activities based on argumentations in the context of science education. Additionally, he suggests that students' involvement in these argumentations develops their communication skills, metacognitive awareness, critical thinking skills and thus their science literacy skills. As tested in $\mathrm{H}_{2}$ hypothesis, science literacy skills predict their attitudes toward science literacy in a meaningful way. This finding shows that students are able to critically analyze, interpret and evaluate scientific texts, and have a causal questioning tendency or attitude towards the information and propositions in these texts. According to this explanation, it is possible to say that the $\mathrm{H} 2$ hypothesis is acceptable. On the other hand, as assumed in hypothesis $\mathrm{H}_{3}$, an individual applying critical reading skill can be said to have a questioning attitude or a tendency towards the information, concept or propositions in science texts

\section{Recommendations}

In light of these findings, in science education learning experiences and design of units have been recommended based on students' critical thinking skills and critical reading skills. In learning environment, while teaching the concepts, information and process about science to students, teachers should make use of critical reading strategies that allow students to question, analyze, interprete and evaluate better. This will allow a more effective and permanent science learning and resulty, the student will reach the science literacy, which is one of the goals of science teaching. Student learning has a permanent program that gains access to science literacy is one of the goals. With science literacy, as put forth theoretically, too, the communalization of studies regarding the planning, application and evaluation of thinking-oriented science units based on higher order thinking skills has been considered.

\section{References}

Akın, F., Koray, Ö. \& Tavukçu, K. (2014). How effective is critical reading in the understanding of scientific texts?. Procedia - Social and Behavioral Sciences, 174(12), 2444 - 2451.

Arbuckle, J. L. (2008). Amos 17.0 user's guide. Crawfordville, FL: Amos Development Corporation.

Aregu, B. B. (2013). A study of self-regulated learning strategies as predictors of critical reading. Educational Research and Reviews, 8(21), 1961-1965.

Arons, A. B. (1983). Achieving wider scientific literacy. Daedalus, 112(2), 91-122.

Baron, R. M. ve Kenny, D. A. (1986). The moderator-mediator variable distinction in social psychological research: Conceptual, strategic, and statistical considerations. Journal of Personality and Social Psychology, 51(6), 1173-1182.

Bentler, P. M. (2006). EQS 6 structural equations program manual. Encino, CA: Multivariate Sofware, Inc.

Blake, C. (2015). Teaching science literacy to all grade levels. http://online.cune.edu/teaching-science-literacy/ adresinden erişilmiştir.

Burnett, E. H. \& Berg, P. C. (1988). Reading 1nstruction in the schools: 1mproving students' critical thinking skills. The Clearing House: A Journal of Educational Strategies, Issues and Ideas, 61(5), 208-210.

Cavagnetto, A. R. (2010). Argument to foster scientific literacy: A review of argument interventions in K-12 science contexts. Review of Educational Research, 80(3), 336-371.

Center for Science, Mathematics, and Engineering Education (1998). Every child a scientist: Achieving scientific literacy for all. Washington: National Academy Press,

Christensen, L. B., Johnson, R. B. ve Turner, L. A. (2015). Araştırma yöntemleri: Desen ve analiz (A. Aypay, Çev.). Ankara: Anı Yayıncılık. 
Criscuolo, N. P. (1965). A plea for critical reading in the primary grades. Peabody Journal of Education, 43(2), 107-112.

Cromley, J. G. (2009). Reading achievement and science proficiency: International comparisons from the programme on international student assessment. Reading Psychology, 30(2), 89-118.

DeVoogd, G. L. (2007). Critical comprehension of social studies texts. Random House Inc: An annual magazine for Educators, 2, 21-24.

Fives, H.; Huebner, W.; Birnbaum, A. S.ve Nicolich, M. (2014). Developing a Measure of Scientific Literacy for Middle School Students. Science Education, 98(4),549-580.

Geithner, C. A. \& Pollastro, A. N. (2016). Doing peer review and receiving feedback: impact on scientific literacy and writing skills. Advances in Physiology Education, 40(1), 38-46.

Genç, M. (2015). The effect of scientific studies on students' scientific literacy and attitude. OMU J. Fac. Educ., 34(1), 141-152.

Güçlüer, E. ve Kesercioğlu, T. (2012). The effect of using activities improvıng scientific literacy on students' achievement in science and technology lesson. International Online Journal of Primary Education, 1(1), 8-13.

Hackling, M. ve Sherriff, B. (2015). Language-based reasoning in primary science. Teaching science, 61(2), 1425.

Hicks, R. ve Tingley, D. (2011). Causal mediation analysis. The Stata Journal, 11(4), 1-15.

Holbrook, J. ve Rannikmae, M. (2009). The meaning of scientific literacy. International Journal of Environmental \& Science Education, 4(3), 275-288.

Hume, A. (2009). Authentic scientific inquiry and school science. Teaching Science, 55(2), 35-41.

Jenkins, E. (2010). How might research inform scientific literacy in schools?. Education in Science, 239, $26-27$.

Jurecki, K. \& Wander, M. C. F. (2012). Science literacy, critical thinking, and scientific literature: Guidelines for evaluating scientific literature in the classroom. Journal of Geoscience Education, 60(2), 100-105.

Kadir, N. A., Subki, R. N. S., Jamal, F. H. A., \& İsmail, J. (2014). The importance of teaching critical reading skills in a Malaysian reading classroom. The 2014 WEI International Academic Conference Proceedings, Indonesia.

Khabiri, M. \& Pakzad, M. (2012). The Effect of Teaching Critical Reading Strategies on EFL Learners' Vocabulary Retention. The Journal of Teaching Language Skills, 4(31), 73-106.

Kline, R. B. (2011). Principles and practice of structural equation modeling (3. bs.). New York/London: The Guilford Press.

Kobayashi, K. (2007). The influence of critical reading orientation on external strategy use during expository text reading. Educational Psychology, 27(3), 363-375

Lawson, A. E. (2010). Basic inferences of scientific reasoning, argumentation, and discovery. Science Education, 94, 336-364.

Lewis, J. (1983). Influence of cognitive and ethical development on critical reading. Journal of College Reading and Learning, 16(1), 15-20.

Lewis, K. A. (2010). Constructing scientific literacy in inquiry-based communities of science practice. (Unpublished Doctorate Thesis), University of California, Santa Barbara.

Lin, H-S., Hong, Z.-R.ve Huang, T-C., (2012). The role of emotional factors in building public scientific literacy and engagement with science. International Journal of Science Education, 34(1), 25-42.

LoGiudici, R. ve Ende, F. (2010). Teaching toward a more scientifically literate society. Science Scope, 33(9), 858-63.

Majima, Y. (2012). The role of critical thinking in acquisition of science literacy and "Subjective demarcation" between science and pseudoscience. Cognitive Studies, 19(1), 22-38.

Malone, P. S. \& Lubansky, J. B. (2012). Preparing data for structural equation modeling: Doing your homework. Rick H. Hoyle (ed.), Handbook of Structural Equation Modeling. New Yok: The Guilford Press.

Marks, R. ve Eilks, I. (2009). Promoting scientific literacy using a sociocritical and problem-oriented approach to chemistry teaching: Concept, examples, experiences. International Journal of Environmental \& Science Education, 4(3), 231-245.

McGregor, D. ve Kearton, G. (2010). What do researchers say about Scientific Literacy in Schools?. Education in Science, 240, 22-23.

M.E.B. (2013). Uluslararası Öğrenci Başarılarını Değerlendirme Programı, PISA Örnek Fen Soruları, retrieved from http://pisa.meb.gov.tr/wp-content/uploads/2015/02/pisa-ornek-sorular- fen.pdf [25.05.2016].

Michalsky, T., Mevarech Z. R. \& Haibi, L. (2009) Elementary school children reading scientific texts: effects of metacognitive instruction. The Journal of Educational Research, 102(5), 363-376.

Norris S. P. \& Phillips, L.M. (2003). How literacy in its fundamental sense is central to scientific literacy. Science Education, 87, 224-240. 
Nwagbo, C. (2006). Effects of two teaching methods on the achievement in and attitude to biology of students of different levels of scientific literacy. International Journal of Educational Research, 45, 216-229.

OECD. (2006). Assessing scientific, reading and mathematical literacy: A framework for PISA 2006. Paris: OECD.

Paul, R. \& Elder, L. (2008). The miniature guide to critical thinking concepts and tools. Dillon Beach, CA: Foundation for Critical Thinking Press.

Schumacker, R. E. ve Lomax, R. G. (2010). A beginner's guide to structural equation modeling. New York: Routledge.

Smith, K., Loughran, J., Berry, A. \& Dimitrakopoulos, C. (2012). Developing scientific literacy in a primary school. International Journal of Science Education, 34(1), 127 - 152.

Ünal, E. (2006). İlköğretim öğrencilerinin eleştirel okuma becerileri ile okuduğunu anlama ve okumaya ilişkin tutumları arasındaki ilişki. Yayımlanmamış Yüksek lisans tezi, Eskişehir Osmangazi Üniversitesi.

Vieira, R. M. \& Tenreiro-Vieira, C. (2016). Fostering scientific literacy and critical thinking in elementary science education. International Journal of Science and Mathematics Education,14(4), 659-680.

Walker, D., Kiefer, K., \& Reid, S. (1994 - 2012). Critical reading. Writing@CSU. Colorado State University. Available at http://writing.colostate.edu/guides/guide.cfm?guideid=31.

Wellington, J. \& Osborne, J. (2001). Language and literacy in science education. Buckingham Philadelphia: Open University Press.

Yu, J. (2013). Science literacy: Reading strategies among secondary reader. Master's Level Graduate Research Conference. Paper 30. Retrieved from http://digitalcommons.brockport.edu/gradconf/2013/program/3 [24.05.2016]

Zabihi, R. \& Pordel, M. (2011). An investigation of critical reading in reading textbooks: A qualitative analysis. International Education Studies, 4(3), 80-87.

\section{Author Information}

\begin{tabular}{ll}
\hline Ersin Karademir & Ufuk Uluçınar \\
Eskişehir Osmangazi University & Uşak University \\
Faculty of Education, Maths and Science Education & Faculty of Education, One Septemper Campus \\
Department Meşelik Campus 26480 Eskişehir & 64200, Uşak \\
Contact e-mail: eekarademir@gmail.com & \\
\hline
\end{tabular}

